\title{
Development of Dribbling Exercise Variation in Learning Football Science in Sports Training Education Students 2018
}

\author{
IrwansyahSiregar \\ Sports Coaching Education Department, FIK \\ UniversitasNegeri Medan \\ Medan, Indonesia \\ irwansyahsiregar02@gmail.com
}

\author{
HevantriSihombing \\ Sports Coaching Education Department, FIK \\ UniversitasNegeri Medan \\ Medan, Indonesia \\ hevantrishb@gmail.com
}

\author{
IfayAndiDamanik \\ Sports Coaching Education Department, FIK \\ UniversitasNegeri Medan \\ Medan, Indonesia \\ ifayandi@gmail.com
}

\begin{abstract}
This study aims to develop a football dribbling exercise learning model in 2018. Contribute knowledge and thoughts that can be used as a guideline for guiding lectures. Improving football dribbling techniques in playing football with different learning methods so that learning is not boring for students. The population in this study amounted to 40 students of Sports Coaching Education. The model that has been made in advance is validated by 4 experts in the field of sports, namely 2 people are football coaches and 2 people are sports academics. The small group test involved 20 students and a large group test involving 40 FIK UNIMED PKO students. The output that will be produced from this study is in the form of books that can be made into continuous dribling learning guidelines. By reviewing the results of the needs analysis, researchers hope that the results of this study will be able to increase students' learning interest in football courses, especially in basic dribbling techniques that can automatically improve student achievement in the field of football.
\end{abstract}

Keywords: Development of Learning Model of Dribbling Exercise, Football

\section{INTRODUCTION}

Basic football is one of the subjects required to be followed by students of the Faculty of Sport Science, especially the Sport Coaching Education study program at Medan State University. In this course, students are expected to be able to master the techniques in the game of football, and the most basic is the basic technique of playing football. In football learning, a student who follows a football course will face a different situation, therefore students must have the technical skills to be able to take part in the football course.The implementation of football lectures with dribbling material that has been carried out by soccer lecturers is still normal, where the learning pattern is still not maximal, unique and interesting without losing the original purpose of the lecture itself. Lecturers are required to be able to design various forms of learning so that lectures become interesting, and not boring.

From the results of evaluations made to students during football lectures, especially dribbling learning, some students said that learning was commonplace, and some even said that they had been / often done in soccer schools where they practiced. Departing from the evaluation, researchers are interested in developing existing forms of dribbling learning to become more interesting and make students become enthusiastic to attend lectures. As understood, a lecturer needs to develop learning models so that lectures become more interesting and useful for students.

Based on the results of the above needs analysis, it can be concluded that students are eager to get an interesting form of dribbling learning model, have elements of play, so that they are more enthusiastic and can assist lecturers in creating learning programs whose purpose is to make students more academic and non-academic and able to master football dribbling skills well.

\section{LITERATURE REVIEW}

1. Basic Techniques For Playing Football

The basic techniques of playing football are ways to play ball and gestures that support the ability to play a ball that stands alone regardless of the actual football game. In football games, students must be able to master the basic techniques of playing true and skilled football. Sarumpaet, et al (2002: 17) suggested, the basic technique of playing football consists of kicking, holding the ball, controlling the ball, dribbling. To be able to master the basic techniques of playing football well, 
proper training is needed and must be supported by good physical conditions.RobertKoger, (2005: 15) categorizes football techniques as consisting of: (a) techniques for covering and kicking a ball (kicking), (b) techniques for stopping or receiving a ball, (c) dribbling techniques, (d) trickery with the ball, (e) heading techniques, (f) techniques for controlling and controlling the ball (controlling), (g) throwing technique, (h) goal keeper technique, (i), Juggling technique.

In the development of modern football, techniques, physical conditions, the development of tactics was studied thoroughly in depth and carefully. Scientifically high-level football presentations and demonstrations are only able to be carried out by students from a young age. They have experienced the development of playing football in a continuous and directed manner. Technique in sports is the ability to carry out movements precisely, quickly and harmoniously. So technique in sports is the skill and ability of humans to move economically and with one goal. To achieve mastery of the basic techniques of playing inevitably a student must do with the principles of a truly careful, systematic engineering movement carried out repeatedly over and over continuously, so as to produce good cooperation between a set of muscle nerves, for the formation of harmonic motion, to produce automation movements.

\section{The Nature of Ball Dribbling}

Dribbling is one of the basic techniques of football. in dribbling a student must be able to control the ball well in order to change direction quickly and precisely. when students do not find friends that can be fed, students must do the dribbling of the ball. Dribbling is most often used by front students when having difficulty penetrating the opponent's defense.DannyMielke (2007) herding (dribbling) is a basic skill in football because all students must be able to master the ball while moving, standing or preparing to perform operands or shots. When students have mastered dribbling skills effectively, their contribution in thecompetition will be very great. Ball accompaniment has several uses, namely as follows: a) To pass the opponent, b) To find the opportunity to give the ball to the friend correctly, c) To hold the ball in control, save the ball if there is no possibility or opportunity to immediately pass the pass to friends.Sucipto, et al (2000: 51) says "Basically dribbling is kicking intermittently or slowly, therefore the part of the foot used in dribbling the ball is the same as the foot used to kick the ball".Based on some of the explanations above it can be concluded that dribbling is one of the abilities to carry the ball in the direction of the desired target using the foot. Ball dribbling skills are one of the important and absolute basics that every football student must master.Sucipto, et al (2000: 28-31) the implementation of dribbling can be divided into three ways, namely: (1)Bringing the ball with the inside of the foot, the implementation: a) Positioning the foot dribbling the same as the kicking position of the ball. b) When dribbling the ball, the knees are bent to facilitate mastery of the ball. c) When the foot touches the ball, look towards the ball and then look at the field situation, d) the two arms maintain the balance beside the body. (2) Bringing the ball of the foot with the outside of the foot, the implementation: a) The foot dribbling the same with the kicking position with the back of the outer leg. b) Both knees slightly bent so that it is easy to handle the ball. c) When the foot touches the ball, the view ball, then look at the situation, d) both arms maintain the balance beside the body. (3) Bringing the ball with the back of the foot, the implementation: a) The position of the dribbling foot is the same as the kicking position with the back of the foot. b) The ball rolling must always be close to the foot, thus the ball is still controlled. c) See the ball when the foot touches, then see the situation and the state of the arm maintain the balance beside the body.

\section{Model Development Concept}

Research is basically an activity or a systematic process to solve problems that are carried out by applying the scientific method. Some experts say about what research is, among others Cooper argues that research is a systematic process of investigation aimed at providing information to solve problems.

Research and development method (Research and Development) is a research method that will produce products that can later be used by the wider community.Sugiyono (2013: 407) method of research and development is to be able to produce certain products used by research that are needs analysis and test the effectiveness of these products so that they can function in the wider community, it is necessary to research to test the effectiveness of these products.Sukmadinata (2005: 164) method of research and development is a process or steps to develop a new product or perfect an existing product that can be accounted for. Research oriented to produce or develop products with the product development process through several steps, namely, needs analysis, product development, and product testing.Development research is not to detail and implement complete interventions, but to improve and adapt innovative needs and aspirations. The development research process is circular or patterned starting from analysis activities, designing, evaluating and revising to the desired goals. The definition described earlier that development research is a research based on making an effective product, starting with needs analysis, product development, and product testing. In this case the research that will be developed is the Development of a Variation Model of Student Soccer Dribling Learning in 2018 Sports Coaching Education

\section{RESEARCH METHODOLOGY}

\section{Development Model}

Research and development is a research that aims to produce products in the form of developing variations of long jump training. Sugiyono (2008: 407) development research method is a method of research to produce certain products, and test the effectiveness of the products mentioned.

2. Characteristics of Developed Models

The target of the research or the use that is the target in the research on the development of a variation model of 
driblinglearning is all second semester Sports Coaching Education students (two) who attend basic football courses.

3. Approaches and Research Methods

The method approach used in this study uses development research methods, according to Nana SyaodihSukmadinata, a process or steps to develop a new product or refine an existing product, which has been accounted for.Sugiono, in order to get the results of certain products, is used in research that is needs analysis and to test the effectiveness of these products so that they can function in the wider community, research is needed to test the effectiveness of these products. Then there will be a small group trial and a large group trial.

4. Data Analysis Techniques

In this development research data analysis techniques used are quantitative descriptive analysis techniques with percentages. This technique is used to analyze quantitative data obtained from the results of the trial of the football dribbling training model through the approach to playing in football sports after that will be evaluated by football lecturers / academics and also football coaches. Each validation instrument variable calculated by the number of percent is then averaged by another variable. Each validator will have a different value. The four validator values which consist of several variables on one model are averaged and that is the reference whether the model is used or not. The formula for processing responses or evaluations from experts is calculated using a percentage formula, namely:

Formula $: P=\frac{\text { Amount of Value Obtained }}{\text { Total number }} \times 100 \%$.

TABLE 3.1. Percentage Analysis of Validation Results on the Model

\begin{tabular}{|l|l|c|}
\hline Prosentage & $\begin{array}{l}\text { Informati } \\
\text { on }\end{array}$ & Mean \\
\hline $\begin{array}{l}80 \% \\
100 \%\end{array}$ & Valid & Used \\
\hline $60 \%-79 \%$ & $\begin{array}{l}\text { Valid } \\
\text { enough }\end{array}$ & Used \\
\hline $50 \%-59 \%$ & less valid & $\begin{array}{c}\text { Replace } \\
\mathrm{d}\end{array}$ \\
\hline$<50 \%$ & Invalid & $\begin{array}{c}\text { Replace } \\
\mathrm{d}\end{array}$ \\
\hline
\end{tabular}

\section{RESULT AND DISCUSSION}

\section{Needs Analysis}

Based on observations made by researchers, it was found that $90 \%$ of the samples agreed with new variations in dribbling learning.

2. Product Design

The products of this study have been contained in videos and manuals for implementing dribbling variations.

3. Results of Design Validation

After being revised by the dribbling trainer and sports academics, the six variations offered are appropriate and feasible to be carried out the next stage.
4. Result and Small Group Testing Phase

From the test results of the instrument carried out by the product experts that have been made by the researcher, it is evaluated according to the instrument that has been made. 3 experts selected by researchers who have been considered competent in their fields. The results of the instrument test concluded that:

a) The dribbling training model of collecting balls is useful, safe, in accordance with the principle of training, the movements are carried out effectively and efficiently, fun movements in accordance with the principles of play and true movement in accordance with the principles of practice. The percentage of the validity of this model is $83 \%$.

b) The dribbling exercise model pursues a useful, safe time, in accordance with the principle of training, the movement is carried out effectively and efficiently, fun movements in accordance with the principles of play and true movement in accordance with the principles of practice. The percentage of the validity of this model is $83 \%$.

c) The pyramid dribbling exercise model is useful, safe, in accordance with the principle of training, the movement is carried out effectively and efficiently, fun movements in accordance with the principles of play and true movement in accordance with the principles of practice. The percentage of the validity of this model is $94 \%$.

d) The dribbling code training model is useful, safe, in accordance with the principle of training, the movement is effective and efficient, fun movements in accordance with the principles of play and true movement in accordance with the principles of practice. The percentage of the validity of this model is $81 \%$.

e) Mdribbling training model is useful, safe, in accordance with the principle of training, the movement is carried out effectively and efficiently, fun movements in accordance with the principles of play and true movement in accordance with the principles of practice. The percentage of validity of this model is $92 \%$.

f) The dribbling $X$ training model is useful, safe, in accordance with the principle of training, the movement is carried out effectively and efficiently, fun movements in accordance with the principles of play and true movement in accordance with the principles of practice. The percentage of validity of this model is $89 \%$.

\section{Product Discussion}

The model becomes a standard or example used in making something. Models can be interpreted as patterns or examples of things that will be produced. Models can also be interpreted as references that become the basis or reference of certain things. Models can be in the form of drawings, plans, mathematical formulations, prototypes, markets and so on. The model is designed to represent reality as it really is, although the model itself is not the reality of the real world, so the training model can be interpreted as a conceptual framework 
that describes and describes systematic procedures in organizing experience in training to achieve certain goals and serve as planning guidelines for trainers, facilitators and tutors in carrying out activities from training. The model becomes very useful to achieve the expected goals.Therefore, it can be explained that the development of movement skills which includes: 1) Effective means that the movement is in accordance with the product that is desired or in other words "product oriented". 2) Efficiency means that the movement is in accordance with the process that should be carried out or in other words "process oriented". 3) Adatif means that the movement is in accordance with the situation and environmental conditions in which the motion is carried out (Yoyo, 200: 35).The dribbling training model in football games must be useful, safe, in accordance with the principle of training, the movement is carried out effectively and efficiently, fun movements in accordance with the principles of play and true movement in accordance with the principles of practice. By following these provisions so that the dribbling training model is useful to be used in improving football dribbling skills.

\section{Conclusion}

Based on the results of the field trials and the results of the researchers' discussion, it can be concluded that: (1)The form of dribbling training model is more effective and efficient to be carried out by 14-15 year olds and can improve player reasoning. (2)With forms of training models that are interesting or not boring, uplifting and happy, the player will be serious and motivated to practice and achieve the goals of the exercise itself. (3) With thedevelopment of a dribbling training model in football, it will be useful to use in enhancing abilities, dribbling itself in both football schools, clubs and formal schools.

\section{REFERENCES}

[1] Mielke, Danny.(2007). Dasar-DasarSepakbola. Bandung: Pakar Raya.

[2] Sarumpaet, (2002), Permainan Besar .Departeman Pendidikan dan kebudayaan.

[3] Harsono. (2001:87) Choaching dan Aspek-aspek Psikologis dalam Coaching. Jakarta: Departemen Pendidikan dan Kebudayaan, Proyek Pengembangan Lembaga Pendidikan.

[4] Koger, Robert. 2005. Latihan Dasar Andalan Sepakbola Remaja. Klaten: PT. Saka Mitra Kompetensi.

[5] Muchtar Remmy. (1992). Olahraga Pilihan Sepakbola. Jakarta: Depdikbud.Dirjendikti.Proyek Pembinaan Tenaga Kependidikan.

[6] Nana Syaodih Sukmadinata. Metode Penelitian Pendidikan (Bandung: Remaja Rosdakarya, 2012),h.164

[7] Sucipto, dkk. (1999/2000). Sepakbola, Jakarta: Derektoral Jendral Pendidikan Dasar dan Menengah, Departemen Pendidikan dan Kebudayaan.

[8] Sajoto, M. (2001). Pembinaan Kondisi Fisik dalam Olahraga. Jakarta: Departemen Pendidikan dan Kebudayaan.

[9] Sugiyono. (2013). Metode Penelitian Pendidikan ( Pendekatan Kuantitatif Kualitatif, dan $R \& D)$, Bandung : Alfabeta. 